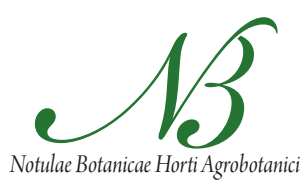

Cluj-Napoca

\title{
Toxicity of Some Cinnamic Acid Derivatives to Common Bean (Phaseolus vulgaris)
}

\author{
AlexandraJITĂREANU, Gabriela TĂTĂRÎNGĂ, Ana-Maria ZBANCIOC, Ursula STĂNESCU \\ University of Medicine and Pharmacy "Gr. T. Popa” Iasi, Faculty of Pharmacy, Universității \\ Street no 16 Iaşi,Romania; alexandrarotariu2@yahoo.com
}

\begin{abstract}
Cinnamic acid derivatives are an important class of biologically active compounds, playing an important role in the plants' development, but may also present a wide range of actions: antimicrobial, antioxidant, antiinflamatory, antitumoral. The present study investigated the toxicity of ten cinnamic acid derivatives on Phaseolus vulgaris, this being the first step in evaluating their pharmacotoxicological potential (usually, plant toxicity tests are used for ecotoxicity assessment, but they can also provide some useful general information about the toxic potential of a pharmaceutical substance to living organisms). The bean seeds were exposed to three different concentrations of each substance $\left(28.6 \mu \mathrm{g} / \mathrm{cm}^{2}, 57.3 \mu \mathrm{g} / \mathrm{cm}^{2}, 114.6 \mu \mathrm{g} / \mathrm{cm}^{2}\right)$. All the tests were conducted in Petri dishes, using an artificial substrate (Whatman filter paper) impregnated with the investigated compounds. The analyzed elements were seedling length, root length, percentage of seeds that developed into seedlings, fresh seedling weight and the total polyphenols content. The tested compounds showed phytotoxic effects, inhibiting the growth of the plants and the biosynthesis of polyphenols as compared to the control. The substances with high logP values showed greater phytotoxic potential, but to establish an exact correlation between hydrophobicity and toxicity of the molecules a QSAR analysis must be further done.
\end{abstract}

Keywords: growth inhibition, Phaseolus test, phytotoxicity, polyphenols content

\section{Introduction}

The cinnamic acid and its derivatives are well known for their biological and pharmacological properties: antimicrobial, antioxidant, antiinflamatory, antitumoral (Da Cunha et al., 2004; Narasimhan et al., 2004). Some cinnamic acid derivatives represent secondary metabolites in plants and they have been the subject of a great number of chemical, biological, agricultural and medical studies, the most important category being the hydroxy-cinnamic acids (Urquiaga and Leighton, 2000).

For pharmaceutical substances the evaluation of their toxicity is very important. Identifying potential toxicity at an early stage in drug discovery can save both time and development costs and reduce the likelihood of late stage failure (Fracchia, 1994).

Usually, plant toxicity tests are used for ecotoxicity assessment (Cleuvers, 2004; Liu, 2009), but they can also provide some useful information about the toxic potential of a pharmaceutical substance. This is the reason why phytotoxicity tests performed on vegetal organisms can be used for o preliminary evaluation of toxicity.

During previous research, a series of cinnamic acid derivatives was synthesized and their antimicrobial activity was evaluated (Jităreanu, 2011; Narasimhan et al., 2004). The majority of the synthesized compounds proved to be moderately active against gram positive bacteria and some were remarkably active against Candida albicans (Jitareanu, 2011).
The purpose of this paper was to assess the phytotoxicity of these compounds in order to obtain some preliminary general information about their toxicological potential.

\section{Materials and methods}

\section{Chemicals}

The tested chemicals were: cinnamic acid $\left(\mathrm{I}_{1}\right)$, caffeic acid $\left(\mathrm{I}_{2}\right)$, ferulic acid $\left(\mathrm{I}_{3}\right)$, 4-hydroxy-cinnamic acid $\left(\mathrm{I}_{4}\right)$, 3, 4-dimethoxi-cinnamic acid $\left(\mathrm{I}_{5}\right)$, 4-methoxi-cinnamic acid $\left(\mathrm{I}_{6}\right)$, 4-chloro-cinnamic acid ( $\left.\mathrm{I}_{7}\right)$, 3-bromo-cinnamic acid $\left(\mathrm{I}_{8}\right)$, 4-(N,N-dimethylamino)-cinnamic acid $\left(\mathrm{I}_{9}\right)$ and 4-methyl-cinnamic acid ( $\left.\mathrm{I}_{10}\right)$ (Fig. 1).

The caffeic acid was purchased from Fluka. All the other substances were synthesized by condensing several benzadehyde derivatives with malonic acid, in the presence of pyridine and piperidine. The structure of the compounds was confirmed by spectral data and quantitative elemental analysis (Jităreanu, 2011).

\section{The plant species}

The plant species selected for this test was Phaseolus vulgaris, one of the plant species recommended by the US FDA (Food and Drugs Administration) for phytotoxicity tests.

The seeds were purchased from an experimental plot, located at the Ezăreni farm, within the U.S.A.M.V. Iasi (Romania). The Phaseolus vulgaris plants were cultivated 
<smiles>[R]c1ccc(/C=C/C(=O)O)cc1[R]</smiles>

$\mathrm{I}_{1}: \mathrm{R}_{1}=-\mathrm{H} ; \mathrm{R}_{2}=-\mathrm{H}$ $\mathrm{I}_{2}: \mathrm{R}_{1}=-\mathrm{OH} ; \mathrm{R}_{2}=-\mathrm{OH}$ $\mathrm{I}_{3}: \mathrm{R}_{1}=-\mathrm{OH} ; \mathrm{R}_{2}=-\mathrm{CH}_{3}$ $\mathrm{I}_{4}: \mathrm{R}_{1}=-\mathrm{OH} ; \mathrm{R}_{2}=-\mathrm{H}$; $\mathrm{I}_{5}: \mathrm{R}_{1}=-\mathrm{OCH}_{3} ; \mathrm{R}_{2}=-\mathrm{OCH}_{3}$ $\mathrm{I}_{6}: \mathrm{R}_{1}=-\mathrm{OCH}_{3} ; \mathrm{R}_{2}=-\mathrm{H}$ $\mathrm{I}_{7}: \mathrm{R}_{1}=-\mathrm{Cl} ; \mathrm{R}_{2}=-\mathrm{H}$; $\mathrm{I}_{8}: \mathrm{R}_{1}=-\mathrm{H} ; \mathrm{R}_{2}=-\mathrm{Br}$ $\mathrm{I}_{9}: \mathrm{R}_{1}=-\mathrm{N}\left(\mathrm{CH}_{3}\right)_{2} ; \mathrm{R}_{2}=-\mathrm{H}$ $\mathrm{I}_{10}: \mathrm{R}_{1}=-\mathrm{CH}_{3} ; \mathrm{R}_{2}=-\mathrm{H}$;

Fig. 1. The structure of the investigated comounds

on a chernozem soil, N.P.K. 20/20/0 complex fertilizer was added and, during the vegetation period, several treatments with Ridomil Plus, Folpan 80 WP and Decis 25 WG were applied for disease control and pests. Recoltation of the seed was done manually. Damaged seeds were discarded.

\section{Preparation of the substrate}

Circles of filter paper (Whatman no.1) with a diameter of $19 \mathrm{~cm}$ were used as artificial substrate. The tested compounds had low solubility in water and for that reason they were dissolved in an appropriate volatile solvent (alcohol). Three alcoholic solutions with concentrations of $0.125 \%, 0.25 \%$ and $0.5 \%$ were made for each substance. The paper circles were dipped in $20 \mathrm{ml}$ solution of the tested compound (at one of the concentrations mentioned above) and impregnated with the alcoholic solution. The volume of solution that remained unabsorbed was measured, enabling the determination of the volume retained by the filter paper (by difference). The circles of paper were dried in an warm air flow to remove the solvent, leaving an uniform coating of the chemical on the filter paper (Dornbos and Spencer, 1990). The amount of substance retained by the paper circles and distributed uniformly on their surface was easily calculated, knowing the concentration of the solution and the volume absorbed. The quantity of substance was reported to the aria of the paper circle $[\mathrm{A}=$ $\left.\pi^{*}(9.5)^{2}=238.385 \mathrm{~cm}^{2}\right]$ and the concentration of active compound was expressed in $\mu \mathrm{g} / \mathrm{cm}^{2}$.

\section{Toxicity test}

The seeds were sterilized with $0.1 \%$ chloramine $\mathrm{T}$ solution for 10 minutes, then rinsed thoroughly with distilled water. The seeds were left for 24 hours in water to inflate. The inflated bean seeds were placed on wet filter papers and kept at $24^{\circ} \mathrm{C}$ to germinate. After 24 hours, the seeds were checked for germination; the seeds that had sprouted were used in the test.

The toxicity tests were conducted in Petri dishes (20 $\mathrm{cm}$ diameter). In each Petri dish a filter paper circle impregnated with active substance (as described above) was placed. The number of seeds used for each dish was 40 . The control group was represented by seeds displayed on a simple filter paper. The control group was identical in every aspect to the test group, except for exposure to the test substance.

The Petri dishes were kept at $24^{\circ} \mathrm{C}$ for 7 days and wet every day with water $(10 \mathrm{ml}$ during the first two days / 20 $\mathrm{ml}$ from day 3 to day 7 ). In the $7^{\text {th }}$ day, the plants were separated from the filter paper and the roots and seedling growth were measured. The percentage of seeds that developed into seedlings was also calculated.

\section{Extraction of polyphenols}

The fresh seedlings were chopped and homogenized. $2 \mathrm{~g}$ of mixture were extracted twice with $30 \mathrm{ml}$ and $15 \mathrm{ml}$ methanol, respectively, under reflux conditions. The determination of total polyphenols was done using the colorimetric protocol for Folin-Ciocalteu, using gallic acid for calibration: to $160 \mu \mathrm{l}$ extract $3040 \mu \mathrm{l}$ distilled water and $200 \mu \mathrm{l}$ Folin-Ciocalteu reagent were added. $600 \mu \mathrm{l}$ sodium carbonate solution (20\%) was added to the mixture after 5 minutes and the absorbance was read after $2 \mathrm{~h}$, at $765 \mathrm{~nm}$.

\section{LogP calculation}

The hydrophobicity (1-octanol/water partition coefficient, $\log \mathrm{P}$ ) of the compounds was calculated using Molinsipration WebMe Editor 3.0.

\section{Statistical analysis}

The experimental data were normally distributed and statistical significance was evaluated using one-way ANOVA analysis, at the 0.05 and 0.01 significance level. All the experiments included three replicates per treatment.

\section{Results and discussion}

The results showed that the tested compounds affected the development of Phaseolus vulgaris seedlings, measured in terms of seedling length, root length, percentage of seeds that developed into seedlings and fresh seedling weight (Tab. 1, 2, 3). The inhibitory effect was different for the analyzed substances and the growth declined with increasing concentration, indicating dose-response behaviour. The highest percentage of inhibition was determined in the case of compounds $\mathrm{I}_{6}, \mathrm{I}_{7}, \mathrm{I}_{8}, \mathrm{I}_{9}$ and $\mathrm{I}_{10}$.

In literature, there is substantial evidence sustaining that plant growth and development is a complex phenomenon, controlled by a multitude of factors. In addition to plant hormones, a variety of external or environmental stimuli can be involved in regulating plant development (Srivastava, 2002). Besides the endogenous growth inhibitors (abscisic acid), there are a number of other naturally occurring organic compounds that exhibit strong biological inhibitory activity when applied exogenously in low concentrations (cinnamic acid and chlorogenic acid) (Gardner et al., 1994; Hopkins, 1995). Trans-cinnamic acid inhibits the activity of auxins and has long been considered an antiauxin (Gardner et al., 1994).

Vishnoi et al. (2009) studied the effect of some substituted cinnamic acids (3-hydroxy, 4-hydroxy, 2-nitro, 3-nitro, 4-nitro, 3-chloro, and 4-methoxy) on germination inhibition on radish, concluding that significant activity was exhibited by all of the compounds. Other studies which showed that cinnamic acid and hydroxycinnamic 
132

Tab. 1. Effect of cinnamic acid derivatives $\left(\mathrm{I}_{1}-\mathrm{I}_{3}\right)$ on the seedling length, root length, percentage of seeds that developed into seedlings and fresh seedling weight

\begin{tabular}{ccccc}
\hline $\begin{array}{c}\text { Compound/ } \\
\text { Concentration }\left(\mu \mathrm{g} / \mathrm{cm}^{2}\right)\end{array}$ & $\begin{array}{c}\text { Seedling lenght } \\
\pm \mathrm{SD}(\mathrm{cm})\end{array}$ & $\begin{array}{c}\text { Root lenght } \\
\pm \mathrm{SD}(\mathrm{cm})\end{array}$ & $\begin{array}{c}\text { Percentage of seeds that } \\
\text { developed into seedlings }(\%)\end{array}$ & $\begin{array}{c}\text { Fresh seedling weight } \\
(\mathrm{g})\end{array}$ \\
\hline Control & $19.84 \pm 0.30$ & $11.40 \pm 0.29$ & 87.50 & 10.85 \\
$\mathrm{I}_{1} / 28.6$ & $13.73 \pm 0.01^{* *}(30.79)$ & $9.16 \pm 0.24^{*}(19.64)$ & 50.00 & 6.05 \\
$\mathrm{I}_{1} / 57.3$ & $12.03 \pm 0.27^{* *}(39.36)$ & $7.14 \pm 0.25^{* *}(37.36)$ & 52.50 & 5.20 \\
$\mathrm{I}_{1} / 114.6$ & $8.25 \pm 0.18^{* *}(58.41)$ & $5.71 \pm 0.17^{* *}(49.85)$ & 35.00 & 3.75 \\
$\mathrm{I}_{2} / 28.6$ & $18.16 \pm 0.58 \mathrm{~ns}(8.46)$ & $7.44 \pm 0.05^{* *}(34.73)$ & 65.00 & 8.64 \\
$\mathrm{I}_{2} / 57.3$ & $18.01 \pm 0.03 \mathrm{~ns}(9.22)$ & $6.38 \pm 0.15^{* *}(44.03)$ & 65.00 & 8.32 \\
$\mathrm{I}_{2} / 114.6$ & $17.46 \pm 0.64^{*}(11.99)$ & $5.82 \pm 0.32^{* *}(48.94)$ & 67.50 & 7.78 \\
$\mathrm{I}_{3} / 28.6$ & $17.74 \pm 0.28 \mathrm{~ns}(10.58)$ & $7.81 \pm 0.05^{*}(31.49)$ & 70.00 & 8.18 \\
$\mathrm{I}_{3} / 57.3$ & $16.94 \pm 0.16 \mathrm{~ns}(14.61)$ & $7.45 \pm 0.02^{* *}(34.64)$ & 62.50 & 6.61 \\
$\mathrm{I}_{3} / 114.6$ & $8.88 \pm 0.53^{* *}(55.24)$ & $7.00 \pm 0.41^{* *}(38.59)$ & 47.50 & 4.62 \\
\hline
\end{tabular}

Values are mean \pm SD for three replicate in each group. ${ }^{*},{ }^{* *}$ indicate values significant at the $\mathrm{p}<0.05, \mathrm{p}<0.01$ level. ns means not significantly. Figures in parentheses represent percent inhibition. The abbreviations used are: cinnamic acid $\left(\mathrm{I}_{1}\right)$, caffeic acid $\left(\mathrm{I}_{2}\right)$, ferulic acid $\left(\mathrm{I}_{3}\right)$.

Tab. 2. Effect of cinnamic acid derivatives $\left(\mathrm{I}_{4}-\mathrm{I}_{7}\right)$ on the seedling length, root length, percentage of seeds that developed into seedlings and fresh seedling weight

\begin{tabular}{ccccc}
\hline $\begin{array}{c}\text { Compound/ } \\
\text { Concentration }\left(\mu \mathrm{g} / \mathrm{cm}^{2}\right)\end{array}$ & $\begin{array}{c}\text { Seedling lenght } \\
\pm \mathrm{SD}(\mathrm{cm})\end{array}$ & $\begin{array}{c}\text { Root lenght } \\
\pm \mathrm{SD}(\mathrm{cm})\end{array}$ & $\begin{array}{c}\text { Percentage of seeds that } \\
\text { developed into seedlings }(\%)\end{array}$ & $\begin{array}{c}\text { Fresh seedling weight } \\
(\mathrm{g})\end{array}$ \\
\hline $\mathrm{I}_{4} / 28.6$ & $17.77 \pm 0.02 \mathrm{~ns}(10.43)$ & $11.16 \pm 0.10 \mathrm{~ns}(2.10)$ & 90.00 & 9.60 \\
$\mathrm{I}_{4} / 57.3$ & $14.55 \pm 0.22^{* *}(26.66)$ & $8.44 \pm 0.09^{* *}(25.96)$ & 82.50 & 9.15 \\
$\mathrm{I}_{4} / 114.6$ & $13.95 \pm 0.15^{* *}(29.68)$ & $7.19 \pm 0.28^{* *}(36.92)$ & 77.50 & 8.50 \\
$\mathrm{I}_{5} / 28.6$ & $12.63 \pm 0.65^{* *}(36.34)$ & $5.5 \pm 0.25^{* *}(51.75)$ & 42.50 & 5.67 \\
$\mathrm{I}_{5} / 57.3$ & $11.84 \pm 0.33^{* *}(40.32)$ & $2.66 \pm 0.17^{* *}(76.66)$ & 37.50 & 4.79 \\
$\mathrm{I}_{5} / 114.6$ & $5.38 \pm 0.17^{* *}(72.88)$ & $1.85 \pm 0.19^{* *}(83.77)$ & 22.50 & 1.06 \\
$\mathrm{I}_{6} / 28.6$ & $7.10 \pm 0.15^{* *}(64.21)$ & $4.00 \pm 0.16^{* *}(64.91)$ & 30.00 & 3.06 \\
$\mathrm{I}_{6} / 57.3$ & $6.38 \pm 0.61^{* *}(67.84)$ & $2.3 \pm 0.11^{* *}(79.82)$ & 22.50 & 1.89 \\
$\mathrm{I}_{6} / 114.6$ & $4.74 \pm 0.18^{* *}(76.10)$ & $1.74 \pm 0.36^{* *}(84.73)$ & 15.00 & 0.75 \\
$\mathrm{I}_{7} / 28.6$ & $6.38 \pm 0.35^{* *}(67.84)$ & $4.95 \pm 0.09^{* *}(56.57)$ & 42.50 & 4.30 \\
$\mathrm{I}_{7} / 57.3$ & $5.38 \pm 0.63^{* *}(72.88)$ & $3.42 \pm 0.14^{* *}(70.00)$ & 37.50 & 3.03 \\
$\mathrm{I}_{7} / 114.6$ & $2.25 \pm 0.15^{* *}(88.56)$ & $2.55 \pm 0.15^{* *}(77.63)$ & 12.50 & 0.55 \\
\hline
\end{tabular}

Values are mean \pm SD for three replicate in each group. ${ }^{*},{ }^{* *}$ indicate values significant at the $\mathrm{p}<0.05, \mathrm{p}<0.01$ level. ns means not significantly. Figures in parentheses represent percent inhibition. The abbreviations used are: 4-hydroxy-cinnamic acid $\left(\mathrm{I}_{4}\right), 3,4$-dimethoxi-cinnamic acid $\left(\mathrm{I}_{5}\right), 4$-methoxi-cinnamic acid $\left(\mathrm{I}_{6}\right)$, 4-chloro-cinnamic acid $\left(\mathrm{I}_{7}\right)$

Tab. 3. Effect of cinnamic acid derivatives $\left(\mathrm{I}_{8}-\mathrm{I}_{10}\right)$ on the seedling length, root length, percentage of seeds that developed into seedlings and fresh seedling weight

\begin{tabular}{ccccc}
\hline $\begin{array}{c}\text { Compound/ } \\
\text { Concentration }\left(\mu \mathrm{g} / \mathrm{cm}^{2}\right)\end{array}$ & $\begin{array}{c}\text { Seedling lenght } \\
\pm \mathrm{SD}(\mathrm{cm})\end{array}$ & $\begin{array}{c}\text { Root lenght } \\
\pm \mathrm{SD}(\mathrm{cm})\end{array}$ & $\begin{array}{c}\text { Percentage of seeds that } \\
\text { developed into seedlings }(\%)\end{array}$ & $\begin{array}{c}\text { Fresh seedling weight } \\
(\mathrm{g})\end{array}$ \\
\hline $\mathrm{I}_{8} / 28.6$ & $6.54 \pm 0.23^{* *}(67.03)$ & $3.37 \pm 0.03^{* *}(70.43)$ & 40.00 & 3.05 \\
$\mathrm{I}_{8} / 57.3$ & $5.62 \pm 0.11^{* *}(71.67)$ & $2.60 \pm 0.05^{* *}(77.19)$ & 40.00 & 2.80 \\
$\mathrm{I}_{8} / 114.6$ & $1.5 \pm 0.10^{* *}(92.43)$ & $1.35 \pm 0.57^{* *}(88.15)$ & 12.50 & 0.15 \\
$\mathrm{I}_{9} / 28.6$ & $8.19 \pm 0.79^{* *}(58.71)$ & $3.54 \pm 0.09^{* *}(68.94)$ & 47.50 & 4.65 \\
$\mathrm{I}_{9} / 57.3$ & $6.51 \pm 0.17^{* *}(67.18)$ & $2.55 \pm 0.08^{* *}(77.63)$ & 35.00 & 3.45 \\
$\mathrm{I}_{9} / 114.6$ & $4.7 \pm 0.28^{* *}(76.31)$ & $1.78 \pm 0.38^{* *}(84.38)$ & 27.50 & 1.63 \\
$\mathrm{I}_{10} / 28.6$ & $9.97 \pm 0.36^{* *}(49.74)$ & $4.36 \pm 0.07^{* *}(61.75)$ & 55.00 & 7.50 \\
$\mathrm{I}_{10} / 57.3$ & $8.01 \pm 0.15^{* *}(59.62)$ & $3.45 \pm 0.14^{* *}(69.73)$ & 57.50 & 5.18 \\
$\mathrm{I}_{10} / 114.6$ & $6.61 \pm 0.24^{* *}(66.68)$ & $3.01 \pm 0.18^{* *}(73.52)$ & 42.50 & 3.90 \\
\hline
\end{tabular}

Values are mean $\pm S D$ for three replicate in each group. ${ }^{*},{ }^{* *}$ indicate values significant at the $\mathrm{p}<0.05, \mathrm{p}<0.01$ level. ns means not significantly. Figures in parentheses represent percent inhibition. The abbreviations used are: 3-bromo-cinnamic acid $\left(\mathrm{I}_{8}\right), 4-\left(\mathrm{N}, \mathrm{N}\right.$-dimethylamino)-cinnamic acid $\left(\mathrm{I}_{9}\right)$ and 4 -methyl-cinnamic acid $\left(\mathrm{I}_{10}\right)$. 


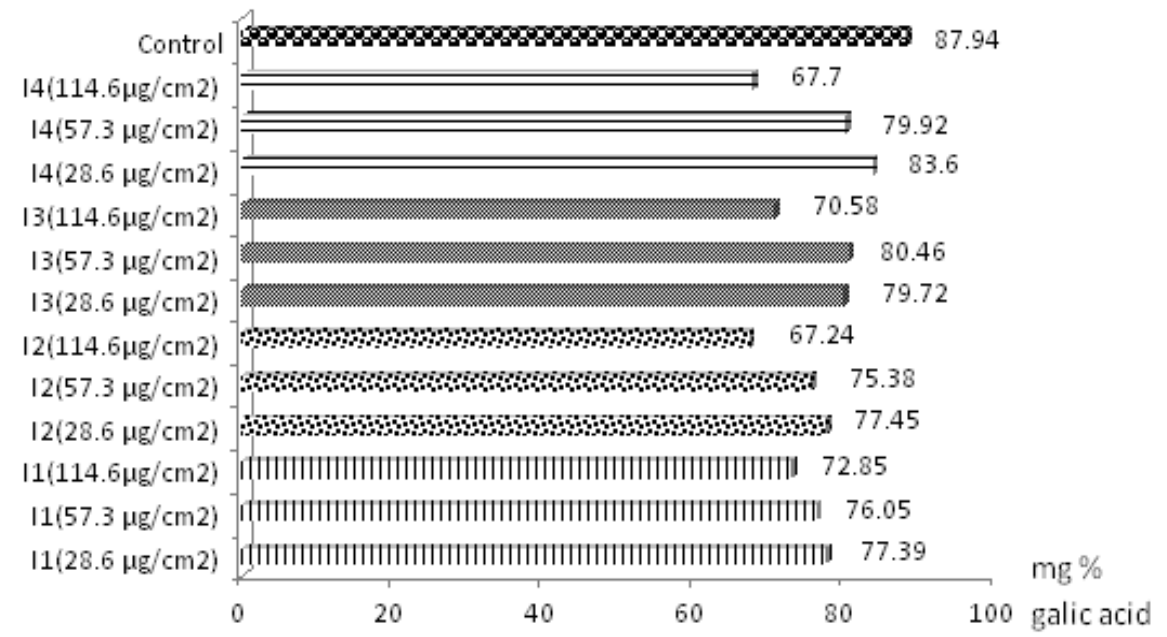

Fig. 2. Changes in the polyphenolic content after treatment with compounds $\mathrm{I}_{1}-\mathrm{I}_{4}$ [cinnamic acid $\left(\mathrm{I}_{1}\right)$, caffeic acid $\left(\mathrm{I}_{2}\right)$, ferulic acid $\left(\mathrm{I}_{3}\right)$, 4-hydroxy-cinnamic acid $\left.\left(\mathrm{I}_{4}\right)\right]$

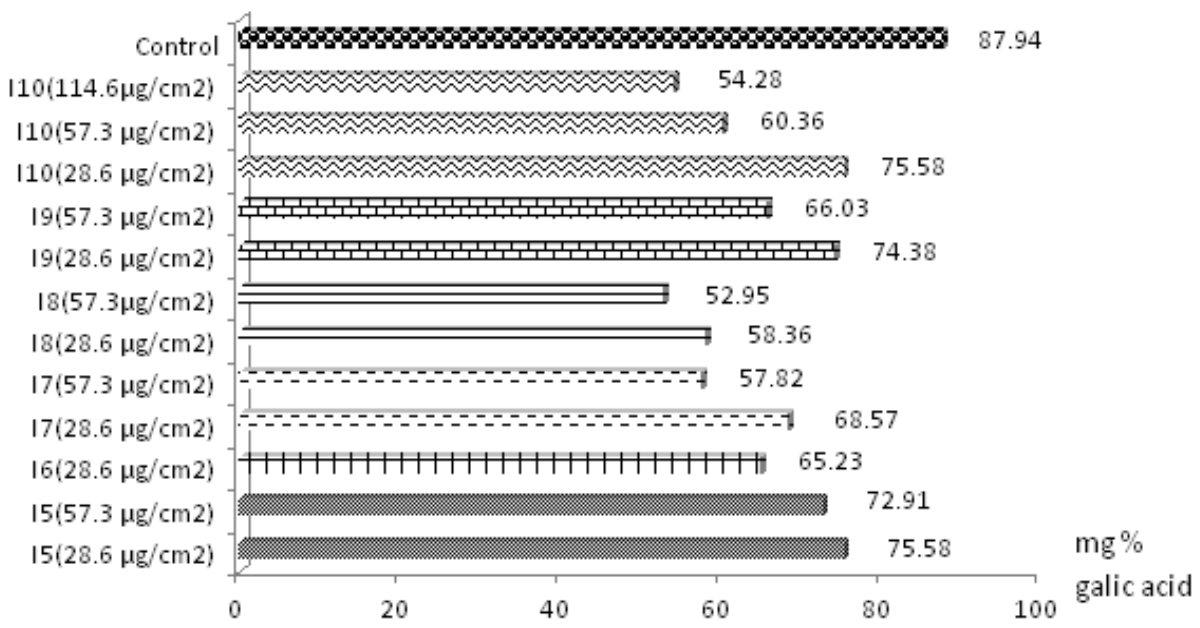

Fig. 3. Changes in the polyphenolic content after treatment with compounds $\mathrm{I}_{5}-\mathrm{I}_{10}[3,4$-dimethoxicinnamic acid $\left(\mathrm{I}_{5}\right), 4$-methoxi-cinnamic acid $\left(\mathrm{I}_{6}\right)$, 4-chloro-cinnamic acid $\left(\mathrm{I}_{7}\right), 3$-bromo-cinnamic acid $\left(\mathrm{I}_{8}\right)$, 4-(N,N-dimethylamino)-cinnamic acid $\left(\mathrm{I}_{9}\right)$ and 4-methyl-cinnamic acid $\left.\left(\mathrm{I}_{10}\right)\right]$

acids were implicated in negative plant-plant interactions including allelopathy (Chaves et al., 2001; Li et al., 2010). There are several mechanisms proposed for phenolic allelochemicals: changes in membrane permeability and inhibition of plant nutrient uptake, inhibition of cell division and elongation, effects on various enzymes function $(\mathrm{Li}$ et al., 2010).

Batish et al. (2010) found that caffeic acid affects early growth, and morphogenetic response of hypocotyl cuttings of mung bean, also proving its phytotoxicity.

According to the results obtained in the present study, treatment with both caffeic and ferulic acid at $28.6 \mu \mathrm{g} / \mathrm{cm}^{2}$ and $57.3 \mu \mathrm{g} / \mathrm{cm}^{2}$ did not significantly affect the growth of the Phaseolus vulgaris seedlings, but a significant inhibition was seen in root length. This phenomenon was previously observed, phenolic acids have been shown to inhibit the length of roots more than shoots ( $\mathrm{Li}$ et al., 1993). However, all the other cinnamic acid derivatives investigated manifested important phytotoxic properties at all three tested concentrations, these results being in agreement with the previously reported data mentioned above. The highest percentages of inhibition in both seedling length and root length were registered for 3-bromocinnamic acid.

Polyphenols represent secondary metabolites in plants and their biosynthesis and accumulation arise from highly regulated processes, which require cell-, tissue-, development- and environment-specific controls. The action of different chemicals may have a great influence on physiology and biochemical processes (Ahemad, 2011; Wronka et al., 1995). The content of total polyphenols decreased after treatment for all the tested substances, in comparison to the control (Fig. 2, 3). This indicates that the analyzed compounds affected the plant's metabolism. The lowest quantity of polyphenols was found in the seedlings obtained after treatment with 3-bromo-cinnamic acid $\left(\mathrm{I}_{8}\right)$. In some cases $\left(\mathrm{I}_{5} / 114.6 \mu \mathrm{g} / \mathrm{cm}^{2} ; \mathrm{I}_{6} / 57.3 \mu \mathrm{g} / \mathrm{cm}^{2} ; \mathrm{I}_{6} / 114.6 \mu \mathrm{g} /\right.$ $\left.\mathrm{cm}^{2} ; \mathrm{I}_{7} / 114.6 \mu \mathrm{g} / \mathrm{cm}^{2} ; \mathrm{I}_{8} / 114.6 \mu \mathrm{g} / \mathrm{cm}^{2} ; \mathrm{I}_{9} / 114.6 \mu \mathrm{g} / \mathrm{cm}^{2}\right)$ the mass of fresh seedling was too reduced to permit the 
134

Tab. 4. Calculated values of $\log P$ for compounds $I_{1}-I_{10}$

\begin{tabular}{lllllllllll}
\hline Compound & $\mathrm{I}_{1}$ & $\mathrm{I}_{2}$ & $\mathrm{I}_{3}$ & $\mathrm{I}_{4}$ & $\mathrm{I}_{5}$ & $\mathrm{I}_{6}$ & $\mathrm{I}_{7}$ & $\mathrm{I}_{8}$ & $\mathrm{I}_{9}$ & $\mathrm{I}_{10}$ \\
\hline
\end{tabular}

$\begin{array}{lllllllllll}\log P & 1.91 & 0.94 & 1.24 & 1.21 & 1.55 & 1.96 & 2.58 & 2.69 & 2.01 & 2.35\end{array}$

The abbreviations used are: cinnamic acid $\left(\mathrm{I}_{1}\right)$, caffeic acid $\left(\mathrm{I}_{2}\right)$, ferulic acid $\left(\mathrm{I}_{3}\right)$, 4-hydroxy-cinnamic acid $\left(\mathrm{I}_{4}\right), 3$, 4-dimethoxi-cinnamic acid $\left(\mathrm{I}_{5}\right)$, 4-methoxicinnamic acid $\left(\mathrm{I}_{6}\right)$, 4-chloro-cinnamic acid $\left(\mathrm{I}_{7}\right)$, 3-bromo-cinnamic acid $\left(\mathrm{I}_{8}\right)$, 4-(N,N-dimethylamino)-cinnamic acid $\left(\mathrm{I}_{9}\right)$ and 4-methyl-cinnamic acid $\left(\mathrm{I}_{10}\right)$

determination of the total polyphenols content, using the technique described above.

In order to establish a connection between the structure and the toxicity of the cinnamic acid derivatives (Wang et al., 2002a; Wang et al., 2002b), the hydrophobicity (1-octanol/water partition coefficient, $\log \mathrm{P}$ ) of the compounds was calculated, results being presented in Tab. 4 .

The highest percentage of growth inhibition and the lowest quantity of polyphenols were determined for the plants grown on substrate impregnated with compounds $\mathrm{I}_{6}, \mathrm{I}_{7}, \mathrm{I}_{8}, \mathrm{I}_{9}$ and $\mathrm{I}_{10}$ which had the highest calculated values for $\log P$. This can be explained by the fact that lipophylic molecules have an easier passage through cell membranes. These results are in accordance to those reported by Wang (2002a, 2002b), but in order to establish an exact correlation between hydrophobicity and phytotoxicity of the compounds a QSAR (quantitative structure-activity relationship) analysis must be further performed (Cronin $e t$ al., 2002).

\section{Conclusions}

The toxicity of ten cinnamic acid derivatives on Phaseolus vulgaris was evaluated. The results indicated that the phytotoxicity of hydroxyderivatives was lower compared to the toxicity of the more lipophilic compounds. The greatest inhibitory effect was noticed for 3-bromo-cinnamic acid. These tests only offer general clues regarding the substances' toxicity; therefore the compounds must be submitted to other test to determine their pharmatoxicological potential.

\section{References}

Ahemad M (2011). A comparatives analysis of tebuconazole mediated phytotoxicity to legumes. J Environ Sci Tehnol 4(6):630-637.

Batish DR, Singh HP, Kaur S, Kohli RK, Yadav SS (2008). Caffeic acid affects early growth, and morphogenetic response of hypocotyl cuttings of mung bean (Phaseolus aureus). J Plant Physiol 165:297-305.

Chaves N, Sosa T, Alías JC, Escudero JC (2001). Identification and effects of interaction phytotoxic compounds from exudate of Cistus ladanifer leaves. J Chem Ecol 27(3):611-621.

Cleuvers M (2004). Mixture toxicity of the anti-inflammatory drugs diclofenac, ibuprofen, naproxen, and acetylsalicylic acid. Ecotoxicol Environ Saf 59:309-315.

Cronin MTD, Dearden JC, Duffy JC, Edwards R, Manga N, Worth AP, Worgan ADP (2002). The importance of hydrophobicity and electrophilicity descriptors in mechanistically-based QSARs for toxicological endpoints. SAR and QSAR in Environl Res 13(1):167-176.

Da Cunha FM, Duma D, Assreuy J, Buzzi FC, Niero R, Campos MM, Calixto JB (2004). Caffeic acid derivatives: in vitro and in vivo anti-inflammatory properties. Free Radic Res 38(11):1241-1253.

Dornbos DL, Spencer GF (1990). Natural products phytotoxicity. A bioassay suitable for small quantities of slightly water-soluble compounds. J Chem Ecol 16(2):339352.

Fracchia GN (1994). European Medicines Research. Perspectives in Pharmacotoxicology and Pharmacovigilance Vol. 7. IOS Press, Amsterdam.

Gardner FP, Pearce RB, Mitchell RL (1994). Physiology of crop plants. Iowa State University Press, Ames.

Hopkins WG (1995). Introduction to plant physiology. John Wiley and Sons Inc., New York.

Jităreanu A, Tataringa G, Zbancioc A-M, Tuchilus C, Stanescu U (2011). Evaluarea actiunii antimicrobiene a unor derivati de acid cinamic. Rev Med Chir Soc Med Nat Iasi 115(3):965971.

Li J, Inoue M, Nishimura H, Mizutani J, Tsuzuki E (1993). Interactions of trans-cinnamic acid, its related phenolic allelochemicals and abscisic acid in seedling growth and seed germination of lettuce. J Chem Ecol 19(8):1775-1787.

Li Z-H, Wang Q, Ruan X, Pan C-D, Jiang D-A (2010). Phenolics and plant allelopathy. Molecules 15:8933-8952.

Liu F, Ying G-G, Tao R, Zhao J-L, Ji-Feng Yang J-F, Zhao L-F (2009). Effects of six selected antibiotics on plant growth and soil microbial and enzymatic activities. Environ Pollut 157:1636-1642.

Narasimhan B, Belsare D, Pharande D (2004). Esters, amides and substituted derivatives of cinnamic acid: synthesis, antimicrobial activity and QSAR investigations. Eur J Med Chem 39(10):827-834.

Srivastava LM (2002). Plant Growth and Development. Hormones and Envinronment. Academic Press, San Diego.

Urquiaga I, Leighton F (2000). Plant polyphenol antioxidants and oxidative stress, Biol Res 33(2):55-64.

Vishnoi S, Agrawal V, Kasana VK (2009). Synthesis and Structure-Activity Relationships of Substituted Cinnamic Acids and Amide Analogues: A New Class of Herbicides. J Agric Food Chem 57(8):3261+3265.

Wang X, Yu J, Wang Y, Wang L (2002a). Mechanism-based quantitative structure-activity relationships for the inhibition of substituted phenols on germination rate of Cucumis sativus. Chemosphere 46(2):241-250.

Wang X, Wang Y, Chunsheng Y, Wang L, Han S (2002b). Mechanism-based quantitative structure-phytotoxicity relationships comparative inhibition of substituted phenols on root elongation of Cucumis sativus. Arch Environ Contam Toxicol 42(1):29-35.

Wronka M, Kuras M, Tykarska T, Podstolski A, Zobel AM (1995). Inhibition of the production of phenolic compounds in Brassica napus 2-amino-oxyacetic acid. Ann Bot 75:319-324. 